\title{
Duodenal morphology in calves fed liquid diets with different frequency*
}

\author{
B. Niwińska \\ National Research Institute of Animal Production, \\ Department of Animal Nutrition and Feed Science \\ 32-083 Balice, Poland
}

\begin{abstract}
At the age of 7 days twenty-four bull-calves were divided into 4 groups that received whole milk or milk replacer one or three times per day. Their duodenal morphology on day 36 of life and rearing performance from days 7 to 36 of life were assessed. Feeding frequency affected villus height and daily weight gains $(\mathrm{P} \leq 0.05)$. The duodenum weight, villus height, submucosa thickness, daily weight gains, liquid feed and nutrient utilization per $\mathrm{kg}$ of weight gain were influenced by type of liquid feed $(\mathrm{P} \leq 0.05)$.
\end{abstract}

KEY WORDS: duodenum, calf, feeding frequency, milk, milk replacer

\section{INTRODUCTION}

The gut mucosa in calves can be modified in response to nutritional regime (Baldwin et al., 2000). Marked effects on duodenal morphology by the duration of feeding colostrum and of type of protein used in the diet have been observed (Blättler et al., 2001). Given that the frequency of feeding liquid diets affects calf performance (Strzetelski et al., 2001), it seems that it may be an additional factor influencing duodenal morphology in calves.

The objective of this study was to investigate the effects of the frequency of feeding milk or milk replacer on duodenal morphology on day 36 of life and on rearing performance from days 7 to 36 of life in calves.

\section{MATERIAL AND METHODS}

The experiment was carried out on 24 clinically healthy bull calves (cross- breed Black-and-White with Holstein-Fresian), divided at the age of 7 days into 4 groups

\footnotetext{
* The study was performed as part of the statutory activities of the National Research Institute of Animal Production, Project No. 23217.1

${ }^{1}$ Corresponding author: e-mail: niwb@izoo.krakow.pl
} 
(6 animals per group). The calves in Group 1M and 1MR received whole milk or an isonitrogenous solution of milk replacer, respectively, once a day. Those in Group $3 \mathrm{M}$ and $3 \mathrm{MR}$ received whole milk or the milk replacer, respectively, three times a day. Milk replacer protein originated from (\%): soya concentrate, 60 and whey, 40. The calves were kept in individual cages and intake of feed was monitored. All of the calves were given the same concentrate mixture to appetite. Body weight was determined on days 7 and 36 of life and shortly before slaughter. On day 36 of life, 3 calves from each group were slaughtered two $h$ after the morning feeding and within 10-15 min a segment of the small intestine (from the gastric pylorus to the duodenojejunal flexure) was excised. Tissue samples were removed for histological analysis according to Blättler et al. (2001). Morphometric analyses were conducted with a Zeiss Axioscop (Zeiss GmbH) connected to a camera (CCD ZVS-47DE, Optronics Inc.) computer-linked system (Soft Imaging System $\mathrm{GmbH}$ ). The distance from the crypt opening to the villus tip was determined as villus height; from the base of a crypt to the level of the crypt opening, as crypt depth, and from the end of the circular muscularis to the base of the muscularis mucosae, as the submucosa thickness.

The feeding schedule, feed evaluation and balancing of concentrate mixture were carried out according to the IZ-INRA (2001) system. Proximate analysis of feeds was performed according to standard methods. Data were analysed statistically by ANOVA based on two main effects (1-feeding frequency, 2- liquid feed type) and interaction $(1 \times 2)$ using the analysis of variance procedure of STATISTICA (ver. 5.1). Significant differences were claimed at $\mathrm{P} \leq 0.05$.

\section{RESULTS}

Nutrient content and feed value are given in Table 1.

Feeding frequency affected villus height and daily weight gains $(\mathrm{P} \leq 0.05$; Table 2). The type of liquid feed influenced the duodenum weight, villus height,

Table 1. Nutrient content and nutritive value of feed

\begin{tabular}{lccccccccc}
\hline & \multicolumn{8}{c}{ In 1 kg of feed, g } & \\
\cline { 2 - 8 } Item & $\begin{array}{c}\text { dry } \\
\text { matter }\end{array}$ & $\begin{array}{c}\text { crude } \\
\text { protein }\end{array}$ & $\begin{array}{c}\text { ether } \\
\text { extract }\end{array}$ & $\begin{array}{c}\text { crude } \\
\text { fibre }\end{array}$ & ash & $\begin{array}{c}\text { digested } \\
\text { protein }^{1}\end{array}$ & PDIN $^{2}$ & PDIE $^{2}$ & UFL $^{2}$ \\
\hline $\begin{array}{l}\text { Cow's milk } \\
\text { Milk replacer }\end{array}$ & 125.6 & 33.5 & 40.1 & - & 7.5 & 31.8 & - & - & 0.24 \\
$\begin{array}{l}\text { solution } \\
\begin{array}{l}\text { Concentrate } \\
\text { mixture }\end{array}\end{array}$ & 158.2 & 34.2 & 24.4 & 1.6 & 12.1 & 32.4 & - & - & 0.24 \\
\hline
\end{tabular}

${ }^{1}$ digested crude protein was estimated according to INRA (1989)

${ }^{2}$ nutritional value of feeds expressed: rumen-undegraded dietary protein and microbial protein, synthesized in the rumen when other nutrients and energy (PDIN) or dietary protein (PDIE) are not limiting factors, that are digested in the small intestine; net energy value for milk production (UFL) 
submucosa thickness, daily weight gains and utilization of liquid feed and nutrient per $\mathrm{kg}$ of weight gain $(\mathrm{P} \leq 0.05)$. Calves in all groups utilized similar amounts of concentrate mixture per $\mathrm{kg}$ of weight gain $(\mathrm{P}>0.05)$.

Table 2. Morphology of calf duodenum on day 36 of age, and daily weight gains, feed and nutrient utilization per kg of weight gain when milk (1M) or milk replacer (1MR) fed once or three times per day (3M) or (3MR), respectively, to calves from days 7 to 36 of age

\begin{tabular}{|c|c|c|c|c|c|c|c|c|c|}
\hline \multirow{2}{*}{ Traits } & \multicolumn{4}{|c|}{ Groups } & \multirow{2}{*}{ Mean } & \multirow{2}{*}{ SEM $^{1}$} & \multicolumn{3}{|c|}{ Effects $^{1}$} \\
\hline & $1 \mathrm{M}$ & $1 \mathrm{MR}$ & $3 \mathrm{M}$ & $3 \mathrm{MR}$ & & & 1 & 2 & $1 \times 2$ \\
\hline \multicolumn{10}{|c|}{ Morphology of calf duodenum on day 36 of age } \\
\hline weights ${ }^{2}, \%$ & 0.28 & 0.31 & 0.29 & 0.38 & 0.31 & 0.01 & & $* *$ & $\mathrm{~T}$ \\
\hline villus height, $\mu \mathrm{m}$ & 505 & 498 & 491 & 438 & 483 & 10.7 & $*$ & * & $\mathrm{T}$ \\
\hline villus height/ crypt depth & 2.52 & 2.55 & 2.39 & 2.06 & 2.38 & 0.09 & $\mathrm{~T}$ & $\mathrm{~N}$ & $\mathrm{~N}$ \\
\hline thickness of submucosa, $\mu \mathrm{m}$ & 189 & 220 & 217 & 229 & 211 & 6.06 & $\mathrm{~T}$ & * & $\mathrm{T}$ \\
\hline Daily weight gains, g; & 615 & 407 & 836 & 428 & 572 & 58.8 & $*$ & ** & $\mathrm{T}$ \\
\hline \multicolumn{10}{|l|}{ Utilization per $1 \mathrm{~kg}$ of weight gain } \\
\hline liquid feed, $\mathrm{kg}$ & 9.19 & 16.95 & 9.32 & 15.99 & 12.86 & 1.62 & $\mathrm{~N}$ & ** & $\mathrm{N}$ \\
\hline concentrate mixture, $\mathrm{kg}$ & 0.15 & 0.10 & 0.12 & 0.17 & 0.13 & 0.03 & $\mathrm{~N}$ & $\mathrm{~N}$ & $\mathrm{~N}$ \\
\hline $\mathrm{PDI}^{3}, \mathrm{~g}$ & 312 & 562 & 316 & 543 & 433 & 45.1 & $\mathrm{~N}$ & $* *$ & $\mathrm{~N}$ \\
\hline $\mathrm{UFL}^{4}$ & 2.85 & 4.19 & 2.42 & 4.29 & 3.31 & 0.36 & $\mathrm{~N}$ & $*$ & $\mathrm{~N}$ \\
\hline
\end{tabular}

${ }^{1}$ values are means; $\mathrm{SEM}=$ standard error of mean; $\mathrm{N} \mathrm{P}>0.1 ; \mathrm{T} \mathrm{P} \leq 0.1 ;{ }^{*} \mathrm{P} \leq 0.05 ; * * \mathrm{P} \leq 0.01$, effects: 1 of feeding frequency; 2 of liquid feed type and of interaction $(1 \times 2)$

${ }^{2}$ weights of duodenum are presented as a percentage of empty body weight (EBM)

${ }^{3}$ protein digested in the small intestine; ${ }^{4}$ Feed Unit for Lactation

\section{DISCUSSION}

This study demonstrates that increasing the frequency of feeding liquid feed affected the duodenal morphology in calves aged 36 days. The effects were most marked in calves that received milk replacer, and were reflected in higher duodenum weights and submucosa thickness and lower villus height. The causes of the differences are unknown, although diet is thought to play an important role. Feeding of protein not clotting in the abomasum resulted in significant changes of abomasal luminal $\mathrm{pH}$ (from 1.4 to 6.0) and also in an increased percentage of a low-pH period in a 24-h recording (Ahmed et al., 2002). In response to acid exposure, an increase in alkaline secretion activity of submucosal glands and increase in arterial blood pressure were observed in rat duodenum (Akiba et al., 1999). Baldwin et al. (2000) noted that an increase in the intestinal mass resulted from stimulation of cell proliferation by volatile fatty acid administration. The lower villus size found in our study points to increased apoptotic rates and shorter survival times of villus cells (Blättler et al., 2001). It seems that the duodenal morphology in calves receiving milk replacer was influenced in part by a mucosal reaction to duodenal lumen $\mathrm{pH}$. The calves were nevertheless able to utilize the ingested feed with a similar efficiency despite the differences in duodenal morphology. The effects of the higher feeding frequency on duodenal morphology 
in calves receiving whole milk were less marked. The milk protein clotting effect resulted in a beneficial, additional continuous supply of nutrients, and the digestive tract released bioactive substances evoking favourable nutritional responses (Clare and Swaisgood, 2000).

In conclusion, this study demonstrates that increasing feeding frequency affected duodenal morphology, but the differences can be considered of questionable biological importance because they were not reflected in feed or nutrient utilization per kg of weight gain

\section{REFERENCES}

Ahmed A.F., Constable P.D., Misk N.A., 2002. Effect of feeding frequency and route of administration an abomasal luminal $\mathrm{pH}$ in dairy calves fed milk replacer. J. Dairy Sci. 85, 15021508

Akiba Y., Gutz P.H., Engel E., Naststkin I., Kaunitz J.D., 1999. Acid-sensing pathways of rat duodenum. Amer. J. Physiol. 227, G268-G274

Baldwin R.L., 2000. Sheep gastrointestinal development in response to different dietary treatments. Small Ruminant Res. 35, 39-47

Blättler U., Hammon H.M., Morel C., Philipona C., Rauprich A., Rome V., Hëuron-Luron I., Guilloteau P., Blum J.W., 2001. Feeding colostrum, its composition and feeding duration variably modify proliferation and morphology of the intestine and digestive enzyme activities of neonatal calves. J. Nutr. 131, 1256-1263

Clare D. A., Swaisgood H.E., 2000. Bioactive milk peptides: A Prospectus. J. Dairy Sci. 83, 1187-1195

INRA, 1989. Alimentation des Bovins, Ovins, Caprins. R. Jarrige (Editor). Paris

IZ-INRA, 2001. Standards of Cattle, Sheep and Goats Feeding (in Polish). National Research Institute of Animal Production (Editor). Balice (Poland)

Strzetelski J.A., Niwińska B., Kowalczyk J., Jurkiewicz A., 2001. Effect of replacer feeding frequency and level on concentrate intake and rearing performance of calves. J. Anim. Feed Sci. 10, 413-420

\section{STRESZCZENIE}

\section{Morfologia dwunastnicy cieląt karmionych z różną częstotliwością paszą płynną}

24 buhajki w 7-mym dniu życia przydzielono do 4 grup żywieniowych, w których cielęta otrzymywały jednorazowo lub trzy razy w ciagu dnia mleko krowie lub pójło z preparatu mlekozastępczego. Badano morfologię dwunastnicy w 36 dniu życia oraz wyniki odchowu cieląt od 7 do 36 dnia życia. Częstotliwość karmienia wpłynęła na długość kosmków jelitowych i dzienne przyrosty masy ciała cieląt $(\mathrm{P} \leq 0,05)$. Rodzaj paszy płynnej wpłynął na ciężar dwunastnicy, długość kosmków jelitowych, grubość błony podśluzówkowej, dzienne przyrosty masy ciała oraz wykorzystanie składników pokarmowych na $1 \mathrm{~kg}$ przyrostu masy ciała $(\mathrm{P} \leq 0,05)$. 